\title{
"Legal history" in the making: HM Advocate v Sinclair and the Double Jeopardy (Scotland) Act 2011
}

The longstanding principle of double jeopardy is, simply put, the rule that once acquitted, an accused person cannot be re-prosecuted for the same offence. ${ }^{1}$ Various rationales have been advanced for the principle. ${ }^{2}$ Permitting re-prosecution might increase the risk of wrongful conviction, ${ }^{3}$ encourage complacency in the initial investigation ${ }^{4}$ or cause distress to the accused who has to go through a second trial. ${ }^{5}$ The most convincing arguments, however, are based on the value of finality in the criminal process. A strict double jeopardy rule ensures that acquitted persons can get on with their lives without having to live in perpetual fear of re-prosecution, jury verdicts cannot be accepted or rejected at will by the State and the financial cost of multiple trials is avoided. ${ }^{6}$

The Double Jeopardy (Scotland) Act $2011^{7}$ introduced three limited exceptions to the rule, ${ }^{8}$ namely where the acquittal was tainted because a person committed an offence against the course of justice in relation to the original proceedings (section 2); where the acquitted person subsequently admits to committing the original offence (section 3); and where there is new evidence that the acquitted person committed the original offence (section 4). ${ }^{9}$ Sections 2 and 3 apply regardless of the seriousness of the offence. Section 4 applies only where the original prosecution was on indictment in the High Court. ${ }^{10}$

\section{A. HM ADVOCATE v SINCLAIR}

HM Advocate $v$ Sinclair ${ }^{11}$ is the first case to be re-prosecuted under the Act. Aside from its symbolic significance, it is important because it sheds some light on how section 4 of the Act will be interpreted. Angus Sinclair was initially prosecuted in 2007 for his alleged role in the rape and murder of two women in 1977. It was alleged that he had acted in concert with his brother-in-law, Gordon Hamilton, who died in 1996 and was never prosecuted. Sinclair was acquitted following a successful no case to answer

\footnotetext{
${ }^{1}$ Or for a different offence arising out of the same facts. The principle is now set out in s 1 of the Double Jeopardy (Scotland) Act 2011 but was previously recognised under the common law: see J Chalmers and F Leverick, Criminal Defences and Pleas in Bar of Trial (2006) ch 15.

${ }^{2}$ Summarised by the Scottish Law Commission in its Discussion Paper on Double Jeopardy (DP No 141, 2009) paras 2.19-2.37 (henceforth "Discussion Paper"). See also I Dennis, "Rethinking double jeopardy: justice and finality in criminal process" [2000] Crim LR 933; P Roberts, "Justice for all: two bad arguments (and several good suggestions) for resisting double jeopardy reform" (2002) 6 IJEP 197.

${ }^{3}$ Discussion Paper, paras 2.19-2.20.

${ }^{4}$ Discussion Paper, paras 2.21-2.23.

${ }^{5}$ Discussion Paper, paras 2.24-2.29.

${ }^{6}$ Discussion Paper, paras 2.30-2.37.

${ }^{7}$ Henceforth "the Act".

${ }^{8}$ Scotland is not the only common law jurisdiction to have introduced exceptions. See England and Wales (Criminal Justice Act 2003 part 10); Ireland (Criminal Procedure Act 2010 s 8); New Zealand (Criminal Procedure Act 2011 s 154); South Australia (Criminal Law Consolidation (Double Jeopardy) Amendment Act 2008); Queensland (Criminal Code (Double Jeopardy) Amendment Act 2007); New South Wales (Crimes (Appeal and Review) Amendment (Double Jeopardy) Act 2006); and Victoria (Criminal Procedure Act 2009 ch 7A). Cf. the US and Canada where constitutional principles require the maintenance of a strict rule: US Constitution Fifth Amendment; Canadian Charter of Rights and Freedoms s 11(h).

${ }^{9}$ The first two exceptions were recommended by the SLC, but it reached no firm conclusion on whether a new evidence exception should be introduced: Report on Double Jeopardy (Scot Law Com No 218, 2009) para 4.43 (henceforth "Report").

${ }^{10}$ Section 4(1).

11 [2014] HCJAC 131.
} 
submission. ${ }^{12}$ The trial judge held that there was insufficient evidence in law to support the contention that Sinclair's contact with the two women involved violence or that the sexual contact that took place was nonconsensual. ${ }^{13}$ The Crown had, at the time, no right of appeal against that decision. ${ }^{14}$

Once the Act came into force, the Crown lodged an application under section 4 requesting authority to re-prosecute Sinclair on the basis of new evidence implicating him in acts of violence, namely expert evidence interpreting DNA tests on items of clothing belonging to the deceased women. The tests were undertaken between 2011 and 2012 using techniques that were not available at the time of the original trial ${ }^{15}$ and provided support for the contention that Sinclair was involved in using these items as ligatures. ${ }^{16}$ The application was successful and the High Court granted authority for a fresh prosecution. A second trial took place in November 2014 and Sinclair was convicted. ${ }^{17}$

\section{B. THE INTERPRETATION OF SECTION 4}

\section{(1) The new evidence}

Under section 4, the new evidence on which the application is based must be evidence that was not available, and "could not with the exercise of due diligence have been made available", ${ }^{18}$ at the original trial. The case against the acquitted person must be "strengthened substantially" ${ }^{19}$ and the court must be satisfied that it is "highly likely", given the new evidence and the evidence led the original trial, that "a reasonable jury properly instructed would have convicted the person of the original offence". ${ }^{20}$ The new evidence cannot be evidence which was inadmissible at the original trial but, because of changes to evidential rules, has subsequently become admissible. ${ }^{21}$ In Sinclair, the application of these tests was relatively straightforward and they were all satisfied. ${ }^{22}$

\section{(2) The interests of justice}

An application for a fresh prosecution cannot be granted unless it would be in "the interests of justice". ${ }^{23}$ Unlike the equivalent legislation in some jurisdictions, ${ }^{24}$ the Act is silent on the factors that might be taken into account, but the court held that these would include: $:^{25}$

\footnotetext{
12 Para 1.

${ }^{13}$ Para 29.

${ }^{14}$ A right of appeal against a successful no case to answer submission in solemn proceedings has since been introduced (s 107A of the Criminal Procedure (Scotland) Act 1995). Both this reform and the double jeopardy reforms more generally were prompted by Sinclair's original acquittal: see S Wortley, "Law reform after World's End" (2008) 12 EdinLR 293.

15 Para 44.

${ }^{16}$ Para 129.

17 “World's End murders: Angus Sinclair jailed for 37 years", BBC News website, 14 November 2014, http://www.bbc.co.uk/news/uk-scotland-edinburgh-east-fife-29933928.

${ }^{18}$ Section 4(7)(b). Cf. England and Wales where such a failure of due diligence is not an absolute bar to granting an application but is a factor to be considered under the 'interests of justice' test: Criminal Justice Act 2003 s 79(2)(c). ${ }^{19}$ Section $4(7)$.

${ }^{20}$ Section 4(7)(c). Cf. England and Wales where the equivalent legislation does not require the court to second guess the impact of the evidence on a jury but instead asks whether "it appears highly probative of the case against the acquitted person": Criminal Justice Act 2003 s 78(3)(c).

${ }^{21}$ Section 4(4). It is, however, possible to lead such evidence in the subsequent trial if the application is granted: see text accompanying $\mathrm{n} 35$ below.

${ }^{22}$ Paras 124-131.

${ }^{23}$ Section 4(7)(d).
} 
the fact of the acquittal, the effect any publicity attendant thereon might have on a subsequent trial, the importance of the rule against double jeopardy, the importance of finality, the stress which might be caused to an accused, to witnesses, to victims or their families, the seriousness of the crime(s), the nature and strengthening effect of the new evidence and the conduct of the Crown, both at the time of the original trial and since.

In England and Wales, where the equivalent legislation has been in force for longer, the courts have tended to take the approach that where the 'new evidence' test is met, there will be a prima facie case that a fresh prosecution is in the interests of justice and the question for the court is whether there are good reasons to refuse the application. ${ }^{26}$ In Sinclair, the High Court took a similar approach. There was no attempt to explain why a fresh prosecution would be in the interests of justice other than a brief nod to the "utmost seriousness" ${ }^{27}$ of the offence. Instead the discussion focused on one potential impediment to a fair re-trial: prejudicial publicity.

The respondent had argued that the publicity surrounding the case was such that a fair trial could not take place. ${ }^{28}$ The publicity following the original trial had been extensive, ${ }^{29}$ but the court was not persuaded. It took the view that sufficient safeguards - the trial judge's directions, the prohibition of any further publicity and the possibility of the trial taking place in a different geographical location ${ }^{30}$ - existed to guard against the risks posed. ${ }^{31}$ While perhaps a little idealistic, in terms of the faith it places in the ability of the jury to disregard prior publicity, ${ }^{32}$ this is an unsurprising outcome, given the Scottish courts' general attitude towards the plea in bar of trial based on prejudicial publicity, which appears never to have succeeded. ${ }^{33}$ Sinclair has lodged an appeal against his subsequent conviction on the basis that his re-trial was unfair, ${ }^{34}$ but it would be surprising if his conviction was quashed on this basis.

\section{(3) Evidence available at the subsequent prosecution}

A final issue clarified by the court was that once permission has been granted for a fresh prosecution, the Crown is not limited to leading only the evidence that was led at the original trial plus the new evidence on

\footnotetext{
${ }^{24}$ See e.g. Criminal Justice Act 2003 s 79(2) (England and Wales); Criminal Procedure Act 2009 s 327M(1)(d) (Victoria); Criminal Procedure Act 2011 s 154(2) (New Zealand).

${ }^{25}$ Para 103. In doing so, the court has improved on its approach to re-trial following a successful appeal against conviction, where a general 'interests of justice' test applies, but the factors affecting this have been left undefined: J Chalmers and F Leverick, "When should a re-trial be permitted after a conviction is quashed on appeal?" (2009) 74 MLR 721 at 729.

${ }^{26}$ I Dennis, "Quashing acquittals: applying the 'new and compelling evidence' exception to double jeopardy" [2014] Crim LR 247 at 257.

${ }^{27}$ Para 133.

${ }^{28}$ Para 95.

${ }^{29}$ As the respondent noted, this "was a case which brought a law officer to Parliament to explain the Crown position, resulting in a public statement by the Lord Advocate, a change in the law, and this application" (para 95).

${ }^{30}$ In the event, Sinclair's trial took place in Livingston, away from the locus of events in Edinburgh.

${ }^{31}$ Para 132. Similar safeguards were used to justify a re-prosecution in Dobson [2011] EWCA Crim 1255, a case decided under the equivalent legislation in England and Wales. The defendant had previously been acquitted of the murder of Stephen Lawrence and it is difficult to imagine a case involving a higher degree of potentially prejudicial publicity.

${ }^{32}$ See Chalmers and Leverick, Criminal Defences (n 1) paras 18.05-18.07 for discussion of the relevant research in this area.

${ }^{33}$ See Chalmers and Leverick, Criminal Defences (n 1) para 18.03.

34 "World's End murderer to appeal against double murder conviction over lack of fairness", Scottish Legal News, 18 May 2015, http://www.scottishlegal.com/2015/05/18/worlds-end-murderer-to-appeal-against-double-murderconviction-over-lack-of-fairness/.
} 
which the application was based. Any "available, competent evidence", ${ }^{35}$ including evidence available at the original trial, but for whatever reason the Crown chose not to lead, can be used in the subsequent trial. This permission also extends to evidence that was inadmissible at the original trial but, because of subsequent changes to the rules on admissibility, is admissible at the time of the re-prosecution. ${ }^{36}$ This last point is of particular interest given the Scottish Law Commission's controversial proposals to substantially widen the admissibility of bad character evidence in criminal trials. ${ }^{37}$ If these proposals had been law at the time of Sinclair's re-trial, his long history of previous convictions for similar offences ${ }^{38}$ could potentially have been led as evidence against him.

\section{DISCUSSION}

The re-prosecution of Angus Sinclair was described by Lord Matthews in his sentencing remarks as making "legal history". ${ }^{39}$ It is worth noting that it was only possible at all because, contrary to the recommendation of the Scottish Law Commission, the Scottish legislation has retrospective effect. ${ }^{40}$ Other jurisdictions, including Ireland, ${ }^{41}$ New Zealand ${ }^{42}$ and Queensland, ${ }^{43}$ have declined to give retrospective effect to the exceptions, which perhaps accounts for the lack of any applications in these jurisdictions to date. ${ }^{44}$

At the time of writing, two further applications for permission to re-prosecute have been made by the Crown. In both cases the original acquittal was of a murder charge where the trial took place prior to the coming into force of the Act. Permission to re-prosecute has been granted in one, ${ }^{45}$ while the other awaits judgment. ${ }^{46}$ In the Policy Memorandum accompanying the Double Jeopardy Bill, the Scottish Government stated that the exceptions were "expected to affect only a very small number of serious criminal cases" and would most likely be used "infrequently, perhaps once every 5 years". ${ }^{47}$ With three applications in the four years since the Act came into force, ${ }^{48}$ this estimate has been exceeded but the

\footnotetext{
${ }^{35}$ Para 104.

36 Ibid.

${ }^{37}$ Scottish Law Commission, Similar Fact Evidence and the Moorov Doctrine (Scot Law Com No 229, 2012). For criticism of the proposals, see F Stark, "Bad character, bad answer" (2012) 16 EdinLR 420.

${ }^{38}$ See "A life of abuse, rape and murder", BBC News website, 10 September 2007, http://news.bbc.co.uk/1/hi/scotland/edinburgh_and_east/6983515.stm.

39 "World's End murders: judge's sentencing statement", BBC News website, 14 November 2014, http://www.bbc.co.uk/news/uk-scotland-edinburgh-east-fife-30062403.

${ }^{40}$ Section 14 provides that it is immaterial whether the acquittal was before or after the Act came into force. The Scottish Law Commission had, in its Report, recommended retrospective application for tainted acquittals (para 3.63) and admissions (para 4.11) but not for the new evidence exception (para 5.88). For a discussion of the arguments for and against retrospective application, see R L Lippke, "Modifying double jeopardy" (2012) 15 New Criminal LR 511 at 539-540.

${ }^{41}$ Criminal Procedure Act 2010 s 8(1). The provision has been criticised on the basis that it makes the reforms "futile": see G Coffey, "Post-acquittal retrials for serious offences in the Irish criminal justice process: lessons from England and Wales" (2013) 3 Irish Journal of Legal Studies 36 at 66.

${ }^{42}$ Criminal Procedure Act 2011 s 154(6).

${ }^{43}$ Criminal Code (Double Jeopardy) Amendment Act 2007 s 4.

${ }^{44}$ See M McMahon, "Retrials of persons acquitted of indictable offences in England and Australia: exceptions to the rule against double jeopardy" (2014) 38 Criminal Law Journal 159 at 177.

45 "Ronnie Coulter appears in court over Surjit Singh Chhokar death", 25 March 2015, http://www.bbc.co.uk/news/ukscotland-glasgow-west-32053872.

46 "Bid to retry Francis Auld over 1992 Amanda Duffy murder", BBC News website, 8 May 2015, http://www.bbc.co.uk/news/uk-scotland-glasgow-west-32660676.

${ }^{47}$ Double Jeopardy (Scotland) Bill: Policy Memorandum (2010) para 11.

${ }^{48}$ This figure is broadly in line with England and Wales where, at the time of writing, there have been 14 applications since the introduction of similar legislation in 2003. The first 13 are discussed in detail in Dennis (n 26). The 14th is $R v$ $H$ [2014] EWCA Crim 1816.
} 
numbers are still very small. The double jeopardy principle exists for good reasons, but the narrowness of the exceptions in the Act, coupled with their limited use to date only in extremely serious cases, should leave all but the most hardened supporters of an absolute rule satisfied that the reforms have been a positive development.

Fiona Leverick University of Glasgow 